\title{
Chromatic anomalies in Akodontini (Cricetidae: Sigmodontinae)
}

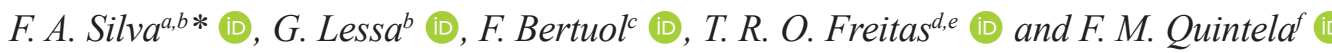

aprograma de Pós-graduação em Ecologia e Conservação, Instituto de Biociências, Universidade Federal de Mato Grosso do Sul - UFMS, Cidade Universitária, CEP 79070-900, Campo Grande, MS, Brasil

bLaboratório de Mastozoologia, Programa de Pós-graduação em Biologia Animal, Museu de Zoologia João Moojen, Universidade Federal de Viçosa - UFV, Vila Gianetti, Casa 32, Campus Universitário, CEP 36571-000, Viçosa, MG, Brasil ‘Laboratório de Evolução e Genética Animal, Programa de Pós-graduação em Genética, Conservação e Biologia Evolutiva, Universidade Federal do Amazonas - UFAM, Av. General Rodrigo Otávio Jordão Ramos, 3000, CEP 69077-000, Manaus, AM, Brasil

dPrograma de Pós-graduação em Genética e Biologia Molecular, Universidade Federal do Rio Grande do Sul - UFRGS, Av. Bento Gonçalves, 1500, CEP 90040-060, Porto Alegre, RS, Brasil

ePrograma de Pós-graduação em Biologia Animal, Departamento de Genética, Universidade Federal do Rio Grande do Sul - UFRGS, Av. Bento Gonçalves, 1500, CEP 90040-060, Porto Alegre, RS, Brasil

fLaboratório de Vertebrados, Programa de Pós-graduação em Biologia de Ambientes Aquáticos Continentais, Universidade Federal do Rio Grande - FURG, Av. Itália, CEP 96203-900, Rio Grande, RS, Brasil

*e-mail: biofaguiar@hotmail.com

Received: September 27, 2018 - Accepted: February 15, 2019 - Distributed: May 31, 2020

(With 1 figure)

The patterns and variability of colors in extant vertebrates are the result of the conjunct action of more than 150 genes that determine pigmentation. Nucleotide alterations in these genes are responsible for differences in pigmentation, which affect visual attraction, aposematism, and camouflage (Hofreiter and Schöneberg, 2010). Among mammals, the two factors that determine color patterns are the presence and distribution of pigments in skin, eyes, and hair (Hofreiter and Schöneberg, 2010; Abreu et al., 2013). However, chromatic abnormalities can occur due to the excess or deficit of melanin, either partially or totally throughout animal's body (Acevedo and Aguayo, 2008; Abreu et al., 2013).

In recent zoological studies, chromatic anomalies have been classified into piebaldism, leucism, albinism, and melanism (Fertl and Rosel, 2002; Miller, 2005; Acevedo and Aguayo, 2008), making the terms "partial" and "total" obsolete when referring to different types of albinism (Summers, 2009; Abreu et al., 2013). Fertl and Rosel (2002) characterized piebaldism as the absence of pigments in some parts of an animal's body. Leucism is characterized by the absence of pigments in most of an animal's body, while the eyes and body extremities are still pigmented. Furthermore, albinism occurs when there is an absence of pigments throughout the body, including the eyes (Fertl and Rosel, 2002; Miller, 2005; Acevedo and Aguayo, 2008). Finally, melanism is characterized by dark coloration of parts of the body due to high melanin deposition (Hubbard et al., 2010).

Many Neotropical vertebrates have been reported with these anomalies, including fishes (e. g. Sazima and Pombal, 1986; Leal et al., 2013), amphibians (e. g. Sanabria et al., 2010), reptiles (e. g. Silva et al., 2010; Ayala-Monedero and Álvarez-León, 2014), birds (e. g. Cavarzere and Tonetti, 2015) and mammals (e. g. Acevedo and Aguayo, 2008; Toledo et al., 2014). However, these anomalies are considered rare in free-ranging populations (Parsons and Bonderup-Nielsen, 1995) due to the assumed short life expectancy of animals carrying these traits, since they would be more susceptible to predation (Sazima and Di-Bernardo, 1991).

Abreu et al. (2013) reported 198 cases from 26 species of Neotropical mammals that presented deficiencies in their melanin production, with only four cases for the order Rodentia. These authors emphasized the importance of knowing the type and frequency of these phenomena to understand the consequences of the anomalous coloration on the survival of wild mammals and the most susceptible taxa. Herein, we present the first reports of piebaldism in the Akodontini rodent Akodon cursor (Winge, 1887) and melanism in Scapteromys tumidus (Waterhouse, 1837).

On March $28^{\text {th }} 2011$, a piebald individual of $A$. cursor (male; head-body length $=129 \mathrm{~mm}$; tail length $=104 \mathrm{~mm}$; body mass $=55 \mathrm{~g}$ ) was captured at the Sítio Boa Sorte ( $21^{\circ} 20^{\prime} 20^{\prime \prime}$ S, $42^{\circ} 45^{\prime} 43^{\prime \prime} \mathrm{W}, 288 \mathrm{~m}$ a.s.1.), located on the border of the municipalities of Cataguases and Dona Euzébia, Minas Gerais state. This area lies within an Atlantic Forest fragment characterized as Submontane Seasonal Semideciduous Forest (Veloso et al., 1991). Species identification was confirmed through comparisons with skulls of $A$. cursor specimens from the mammalian collections, as well as through microscopic analyses of the chromosomes after Giemsa stain procedure, following the morphological classification proposed by Levan et al. (1964). The specimen presented diploid number $(2 n)=14$ and fundamental number $(\mathrm{NF})=20$, which is in agreement 
A

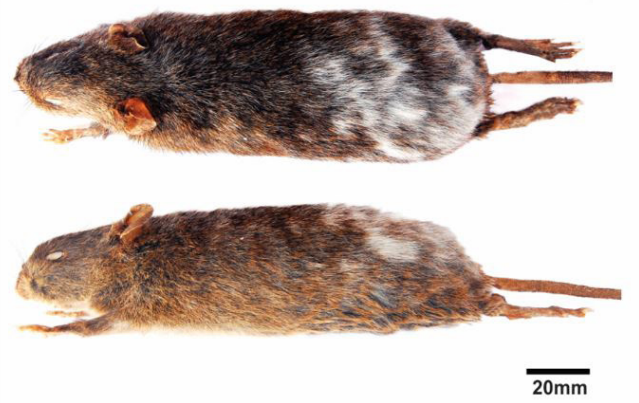

B
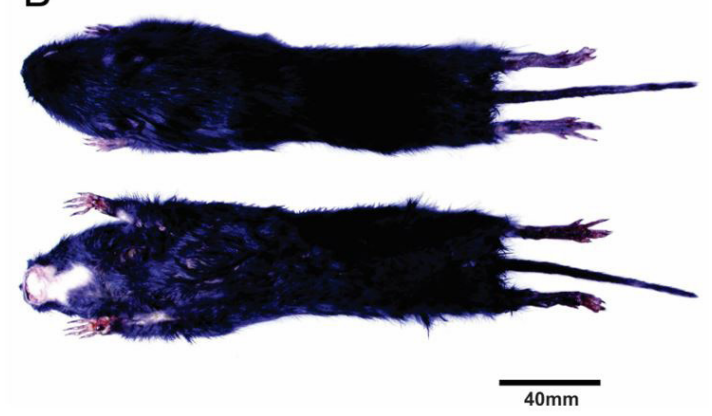

Figure 1. Records of anomalous color in Akodontini. (A) Piebald Akodon cursor found in the Atlantic Forest, Minas Gerais State, southeastern Brazil (Photo: Marcus V. B. de Oliveira). (B) Melanic Scapteromys tumidus found in the Coastal Plain of Rio Grande do Sul State, southern Brazil (Photo: Fernando M. Quintela).

with karyotypic data reported for A. cursor (Di-Nizo et al., 2017). Skull, skin, and tissues of the specimen were deposited into the mammalian collection of "Museu de Zoologia João Moojen da Universidade Federal de Viçosa" (MZUFV 4423), Viçosa, Minas Gerais state, Brazil (Figure 1A).

On September $27^{\text {th }}$ 2011, a melanic individual of S. tumidus (male; head-body length $=136 \mathrm{~mm}$; tail length $=131 \mathrm{~mm}$; body mass $=85 \mathrm{~g}$ ) was captured from a marshy area with predominance of herbaceous Eryngium pandanifolium in “Bujuru” (31³6’34”S, 51²3’40”W), São José do Norte County, Coastal Plain of Rio Grande do Sul State, in southern Brazil. The individual had full darkish dorsum and ventral pelage, except for a small whitish spot in the gular region. Species identification was confirmed through comparisons with skulls of $S$. tumidus specimens from the mammalian collections and cytochrome $b$ (Cytb) sequences obtained from GenBank. Skull, skin, and tissues of the specimen were deposited into the mammalian collection of "Departamento de Genética da Universidade Federal do Rio Grande do Sul” (TR 1588), Porto Alegre, Rio Grande do Sul, Brazil (Figure 1B). Cytb sequence was deposited in GenBank (access number KP233850, haplotype 5; Quintela et al., 2015).

At least 722 native mammal species occur in Brazil, of which more than $34 \%$ are rodents (Percequillo et al.,
2017). In Brazil, chromatic anomalies in rodents have only been reported for Trinomys albispinus (I. Geoffroy, 1838) (Pêssoa and Reis, 1995), Delomys dorsalis (Hensel, 1873) (Cademartori and Pacheco, 1999), Dasyprocta azarae (Lichtenstein, 1823) (Oliveira, 2009) and Thrichomys pachyurus (Wagner, 1845) (Neves et al., 2014). These reports only represent $1.7 \%$ of the rodent species that occur in Brazil. Such low number could be associated with the low position that rodents occupy in the trophic network, since they are more exposed to predation (Abreu et al., 2013). This is the first report of chromatic anomalies occurring in A. cursor and S. tumidus. Such anomalies seem to be rare in both species, considering that a large number of specimens have already been collected.

\section{Acknowledgements}

We are grateful to Guilherme Mourão for the English translation and his suggestions about the manuscript, Marcus V. B. de Oliveira for the Akodon photos, Pollyana A. de Barros for cytogenetic techniques, and ICMBio for the collection license granted (process number 13045-1). This study was financed in part by the Coordenação de Aperfeiçoamento de Pessoal de Nível Superior - Brasil - (CAPES) - Finance Code 001.

\section{REFERENCES}

ABREU, M.S., MACHADO, R., BARBIERI, F., FREITAS, N.S. and OLIVEIRA, L.R., 2013. Anomalous colour in Neotropical mammals: a review with new records for Didelphis sp. (Didelphidae, Didelphimorphia) and Arctocephalus australis (Otariidae, Carnivora). Brazilian Journal of Biology = Revista Brasileira de Biologia, vol. 73, no. 1, pp. 185-194. http://dx.doi. org/10.1590/S1519-69842013000100020. PMid:23644801.

ACEVEDO, J. and AGUAYO, M., 2008. Leucistic South American sea Lion in Chile, with review of anomalously color in otariids. Revista de Biología Marina y Oceanografia, vol. 23, no. 2, pp. 413-417. http://dx.doi.org/10.4067/S0718-19572008000200017.

AYALA-MONEDERO, R.M. and ÁLVAREZ-LEÓN, R., 2014. A report on a case of incomplete leucism in the green iguana (Iguana iguana iguana) (Squamata: Iguanidae) in the Caribbean Colombian. Boletín Científico Museo de Historia Natural, vol. 18, no. 1, pp. 158-162.

CADEMARTORI, C.V. and PACHECO, S.M., 1999. Registro de albinismo em Delomys dorsalis (Hensel, 1872) (Cricetidae, Sigmodontinae). Biociencias, vol. 7, no. 1, pp. 195-197.

CAVARZERE, V. and TONETTI, V.R., 2015. Complete leucism in the Fawn-breasted Tanager Pipraeidea melanonota (Aves: Thraupidae). Boletim do Museu de Biologia Mello Leitão, vol. 37, no. 2, pp. 233-240.

DI-NIZO, C.B., BANCI, K.R.D.S., SATO-KUWABARA, Y. and SILVA, M.J.J., 2017. Advances in cytogenectis of Brazilian rodents: cytotaxonomy, chromosome evolution and new karyotypic dada. Comparative Cytogenetics, vol. 11, no. 4, pp. 833-892. http:// dx.doi.org/10.3897/compcytogen.v11i4.19925. PMid:29362668. 
FERTL, D. and ROSEL, P., 2002. Albinism. In WF. PERRIN, B. WÜRSIG and JGM. THEWISSEN, eds. Encyclopedia of marine mammals. vol. 2. San Diego: Academic Press, pp. 24-26.

HOFREITER, M. and SCHÖNEBERG, T., 2010. The genetic and ecolutionary basis of colour variation in vertebrates. Cellular and Molecular Life Sciences, vol. 67, no. 15, pp. 2591-2603. http://dx.doi.org/10.1007/s00018-010-0333-7. PMid:20229234.

HUBBARD, J.K., UY, J.A.C., HAUBER, M.E., HOEKSTRA, H.E. and SAFRAN, R.J., 2010. Vertebrate pigmentation: from underlying genes to adaptative function. Trends in Genetics, vol. 26, no. 5, pp. 231-239. http://dx.doi.org/10.1016/j.tig.2010.02.002. PMid:20381892.

LEAL, M.E., SCHULZ, U.H., ALBORNOZ, P.L., MACHADO, R. and OTT, P.H., 2013. First Record of Partial Albinism in Two Catfish Species of Genidens (Siluriformes: Ariidae) in an Estuary of Southern Brazil. Brazilian Archives of Biology and Technology, vol. 56, no. 2, pp. 237-240. http://dx.doi.org/10.1590/ S1516-89132013000200008.

LEVAN, A., FREDGA, K. and SANDBERG, A.A., 1964. Nomenclature for centromeric position on chromosomes. Hereditas, vol. 52, no. 2, pp. 201-220. http://dx.doi.org/10.1111/j.1601-5223.1964. tb01953.x.

MILLER, J.D., 2005. All about albinism. Missouri Conservationist, vol. 66 , no. 6 , pp. $4-7$.

NEVES, A.C.S.A., COUTINHO, L.C., OLIVEIRA, M.B. and PÊSSOA, L.M., 2014. First report of partial albinism in genus Thricomys (Rodentia: Echimyidae). Papéis Avulsos de Zoologia. Museu de Zoologia da Universidade de São Paulo, vol. 54, no. 9, pp. 107-110.

OLIVEIRA, S.V., 2009. Albisnismo parcial em cutia Dasyprocta azarae Lichtenstein, 1823 (Rodentia, Dasyproctidae), no sul do Brasil. Biotemas, vol. 22, no. 4, pp. 243-246. http://dx.doi. org/10.5007/2175-7925.2009v22n4p243.

PARSONS, G.J. and BONDERUP-NIELSEN, S., 1995. Partial albinism in an island population of Meadow Voles, Microtus pennsylvanicus, from Nova Scotia. Canadian Field Naturalist, vol. 109 , no. 2 , pp. 263-264.

PERCEQUILLO, A.R., DALAPICOLLA, J., ABREU-JÚNIOR, E.F., ROTH, P.R.O., FERRAZ, K.M.P.M.B. and CHIQUITO, E.A., 2017. How many species of mammals are there in Brazil?
New records of rare rodents (Rodentia: Cricetidae: Sigmodontinae) from Amazonia raise the current known diversity. PeerJ, vol. 5, pp. e4071. http://dx.doi.org/10.7717/peerj.4071. PMid:29259840.

PÊSSOA, A.L. and REIS, S.F., 1995. Coat color variation in Proechimys albispinus (Geoffroy, 1838) (Rodentia, Echimyidae). Boletim do Museu Nacional. Nova Série Zoologia, vol. 361, pp. 1-5.

QUINTELA, F.M., GONÇALVES, G.L., BERTUOL, F., GONZÁLEZ, E.M. and FREITAS, T.R.O., 2015. Genetic diversity of the swamp rat in South America: Population expantion after transgressive-regresive marine events in the Late Quaternary. Mammalian Biology, vol. 80, no. 6, pp. 510-517. http://dx.doi. org/10.1016/j.mambio.2015.08.003.

SANABRIA, E.A., QUIROGA, L.B. and LASPIUR, A., 2010. First Record of partial albinism and scoliosis in Odontophynus occidentalis tadpoles (Anura: Cycloramphidae). Brazilian Archives of Biology and Technology, vol. 53, no. 3, pp. 641-642. http:// dx.doi.org/10.1590/S1516-89132010000300019.

SAZIMA, I. and DI-BERNARDO, M., 1991. Albinismo em serpentes neotropicais. Memorias do Instituto Butantan, vol. 53, no. 2, pp. 167-173.

SAZIMA, I. and POMBAL, J.P., 1986. Um albino de Rhamdella minuta, com nota sobre comportamento (Osteichthyes, Pimelodidae). Brazilian Journal of Biology $=$ Revista Brasileira de Biologia, vol. 46, no. 2, pp. 377-381.

SILVA, F.A., ASSIS, C.L. and QUINTELA, F.M., 2010. Albinism in a Liophis miliaris (Linnaeus, 1758) (Serpentes: Dipsadidade) from Minas Gerais State, southern Brazil. Herpetology Notes, vol. 3, pp. 171-172.

SUMMERS, C.G., 2009. Albinism: classification, clinical characteristics and recent findings. Optometry and Vision Science, vol. 86, no. 6, pp. 659-662. http://dx.doi.org/10.1097/ OPX.0b013e3181a5254c. PMid:19390472.

TOLEDO, G.A.C., GURGEL-FILHO, N.M., ZERMIANI, F.C., AZEVEDO, J.C.N. and FEIJÓ, A., 2014. Albinism in neotropical otter, Lontra longicaudis (Carnivora: Mustelidae). Pan-American Journal of Aquatic Sciences, vol. 9, no. 3, pp. 234-238.

VELOSO, H.P., RANGEL-FILHO, A.L.R. and LIMA, J.C.A., 1991. Classificação da vegetação brasileira, adaptada a um sistema universal. Rio de Janeiro: Fundação Instituto Brasileiro de Geografia e Estatísticas-IBGE, 123 p. 